\title{
Organizational innovation capability as a result of knowledge management processes - a literature review
}

\section{Introduction}

Nowadays, knowledge is treated as one of the basic organizational skills (Yaghoubi et al. 2017, Zurina et al, 2011, Saunila 2014, 2016). As noted by Yaghoubi et al. (2011), combining elements of knowledge in an organization has become one of the most important challenges of the management team, neglecting which may result in reduced creativity of organizations, and thus also in their innovation capability.

It is worth mentioning that knowledge management is treated by some authors as one of the most important issues within the organization (e.g. Dimitrios et.al 2018, Tekin and Akyol 2019). The knowledge management process consists of several elements, its basic component is acquiring knowledge. The second element is knowledge creation, the third one is knowledge sharing and its implementation within the organization. The fourth and final component is the storage of knowledge and documentation (Andreeva

Monika Inków, M.A., University of Zielona Góra, Faculty of Economics and Management, Poland, ORCID: 0000-0002-3179-9404. and Kianto, 2011). Therefore, it can be said that knowledge management is a management discipline dealing with the collection, processing, sharing, use and measurement of the internal and external information 
potential of the organization, which is being done in a systematic way and in order to achieve the set objectives (Yanik 2018, Tekin and Akyol 2019). All knowledge management processes (sharing, acquiring and using knowledge) affect organizational learning and are treated as organizational ability (Yaghoubi et al. 2017; Inkinem 2015; Rifat and Fusun, 2010; Zafarian et al. 2012), while paying attention to organizational learning and creating learning organizations helps promote a culture of innovation and creativity in the workplace and among employees (Meryem et al. 2017). It is worth mentioning that researchers are increasingly pointing to knowledge as an important source of innovation (Wijekoon and Galahitiyawe 2016, Donate and Guadamillas, 2011).

It should be emphasized, however, that in order to be able to effectively develop and introduce new solutions, organizations should have sufficiently high innovation capacity understood as the ability of organizations to improve or modify existing technologies and products, as well as the possibility of creating new ones (Patalas - Maliszewska, Klos 2013). It is also worth noting that the concept of innovation capability is associated with the organizational capabilities of enterprises, as well as with the resources the enterprises possess, which allow them to undertake innovations and to implement them effectively (Stawasz 2014). The theoretical basis for the concept of innovative capacity is the Penrose resource approach, in which the resources and competences owned by the organization are treated as the basic determinants of its long-term results. Therefore, it is assumed that innovations and the competitive advantage resulting from their development and implementation are created within the organizational boundaries, what is more, they are the result of specialized, rare and hard to imitate organizational resources and competences (Stawasz 2014, Obłój 2001).

An extension of the resource-based view is the dynamic capabilities approach defined by Teece $(1997,2007)$ in the late 1990s, according to which dynamic capabilities were defined as the ability of an organization to integrate, reconfigured and build resources and competences in response to rapid environmental changes.

The focal point of this approach is the ability to innovate, creative accumulation of knowledge and an inextricable link between dynamic capabilities and environment (Hewitt-Dundas 2006; Wang, Ahmed 2007, Stawasz 2014).

Furthermore, it is noteworthy that the innovation capability is presented by researchers as a complex, multi-area concept covering many factors of both external and internal nature (Martinez-Roman et al. 2011; Chen et al. 2008; Lawson and Samson 2001). 
As Stawasz (2014) notes, the innovation capability has an impact on both long and short-term results of organizations, and thus also their competitive advantage, however these relationships are mainly the result of the development of dynamic capabilities. It can be stated that in such a system the resources and skills of their transformation create the innovation capabilities that are needed to develop innovations and achieve competitive advantage.

That is why it is extremely important to know the mechanisms related to building and developing the innovative capability of an organization in the context of knowledge management processes. For this reason, the author decided to deal with this topic. The purpose of this study is to show what kind of research problems related to knowledge management in the context of creating and developing innovative capability are most often raised by representatives of science in the world and the second objective is an attempt to answer the question whether innovation capacity can be treated as a result of knowledge management processes.

The article is of epistemological nature, and the author used the method of systematic literature review to achieve her goal, in which she analyzed fulltext articles that were included in the following databases: EBSCO, PROQUEST, ELSVIER, JSTOR, WILEY. The author adopted the following search criteria: research (research paper), keywords: innovation capability. After irrelevant and duplicate articles had been removed, 99 articles were selected to be analyzed, then 34 articles on the studies regarding the problems with knowledge management were shortlisted, and, finally, the research hypotheses, of which there were in total 92, have been analysed.

\section{Innovation capability and knowledge management process}

While analyzing the literature on organizational innovation capacity, one can find more and more voices that it is closely related to the ability of organizations to use knowledge resources (e.g. Romijn and Albaladejo 2002; Subramaniam and Youndt 2005). As noted by Lopez-Nicolas and Merono-Cerdan (2011), knowledge management is one of the factors that affects the ability to innovate.

Darroch (2005), in turn, stated that an organization that can better manage its knowledge resources will eventually be able to transform into a more innovative company. Therefore, knowledge within an organization must be managed and well promoted to guarantee the effectiveness of innovation (Du Plessis 2007).

It is worth noting that the dominant view in the literature is that as part of knowledge management processes, the knowledge sharing process is the most

MONIKA INKÓW 
important for building innovation capability of organizations (e.g. Mazzucchelli et al. In press, Migdali 2019, Sheng, and Hartmann 2019, Tekin , Akyol 2019, Ullah et al .. 2017, Ullah et al .. 2017a, Chang et al..2017, Yesil et al .. 2013). As Reid (2003) stated, sharing knowledge creates an opportunity for an organization to maximize its ability to generate solutions that provide organizations with innovation and allow them to achieve competitive advantage, i.e. to maximize the innovation capability of organizations.

As noted by Ullah et al. (2017), knowledge sharing is primarily about how an employee shares their knowledge, work experience, information and knowhow with other employees in the workplace. It is also worth noting that, unless individual knowledge is shared throughout the organization, it will have a limited impact on the organization itself. Knowledge sharing can take place at both an individual and organizational level. At the individual level, it's all about communicating with each other so that you can do something faster, more efficiently, or so that you can learn from one another, while at the organizational level it's about capturing, organizing, sharing and reusing experience-based knowledge, which is available in the organization and shared with others within the company (Calantone et al., 2002). It can therefore be concluded that knowledge sharing is a process that involves the employee's willingness to communicate with other employees in such a way as to learn from them, while the process of sharing knowledge consists of the processes of gathering and transferring knowledge. It is worth mentioning here that many researchers emphasize the importance of focusing on learning in the organization while shaping its innovation capability (Calantoe et.al. 2002).

A learning-oriented organization can increase its innovation capacity in the three ways. Firstly that it is more likely to become involved in innovative activities and to use the latest technologies. Secondly, such an organization will not miss emerging market opportunities because it has the knowledge necessary to anticipate customer needs. Thirdly, an organization that learns may simply have greater innovation capacity than its competitors, which results from the fact that such an organization constantly monitors the activities of competition on the market, and therefore knows their strengths and weaknesses, and also learns not only from their successes but also from their failures, and all this enables such a company to build high innovation capacity (Calantoe et.al. 2002).

It is also worth adding that the atmosphere that encourages employees to share their knowledge with others and thus to transform individual knowledge into team or organizational knowledge, which improves the knowledge resources available to the organization - can generate new ideas and develop new

Organizational innovation capability as a result of knowledge management processes 
business opportunities, and thus facilitate innovative activities. Moreover, the accumulation of knowledge - internalization and socialization of knowledge, which facilitates the transformation of organizational knowledge into team or individual knowledge - significantly affects the innovative capacity of the company (Ullah et al. 2017, Lin 2007).

\section{Summary of the literature review}

In this section, the author decided to present the research results that were identified in the literature during the review on issues related to knowledge management and innovation capacity. Because some of the studies concerned complex research problems, providing further descriptive statistics could be difficult or impossible, therefore the author decided to sum up the collected material by herself. Table 1 presents the results of the research.

Table 1. Research summary

\begin{tabular}{|c|c|c|c|c|c|}
\hline Author & $\begin{array}{l}\text { Type of innovation } \\
\text { capability }\end{array}$ & $\begin{array}{l}\text { An element of knowl- } \\
\text { edge management af- } \\
\text { fecting the creation of } \\
\text { innovation capability }\end{array}$ & $\begin{array}{l}\text { Positive } \\
\text { impact + } \\
\text { negative } \\
\text { impact- }\end{array}$ & $\begin{array}{l}\text { Sam- } \\
\text { ple } \\
\text { size }\end{array}$ & $\begin{array}{l}\text { Area of } \\
\text { research }\end{array}$ \\
\hline Huang 2011 & $\begin{array}{l}\text { Technological inno- } \\
\text { vation capability }\end{array}$ & Internal learning & + & 328 & Taiwan \\
\hline Yesil et al. 2013 & $\begin{array}{l}\text { Firm innovation ca- } \\
\text { pability }\end{array}$ & Knowledge donating & + & 51 & Turkey \\
\hline Urgal et al. 2013 & $\begin{array}{l}\text { Firm innovation ca- } \\
\text { pability }\end{array}$ & $\begin{array}{l}\text { External Knowledge reso- } \\
\text { urces }\end{array}$ & + & 9432 & Spain \\
\hline $\begin{array}{l}\text { Faroukh and } \\
\text { Sohal } 2015\end{array}$ & $\begin{array}{l}\text { Firm innovation ca- } \\
\text { pability }\end{array}$ & Knowledge collecting & + & 685 & $\begin{array}{l}\text { United } \\
\text { Arab } \\
\text { Emirates }\end{array}$ \\
\hline Liao et al. 2015 & $\begin{array}{l}\text { Firm innovation ca- } \\
\text { pability }\end{array}$ & Knowledge transfer & + & 433 & Taiwan \\
\hline $\begin{array}{l}\text { Hussein et al. } \\
2016\end{array}$ & $\begin{array}{l}\text { Team innovation ca- } \\
\text { pability }\end{array}$ & $\begin{array}{l}\text { Knowledge collecting } \\
\text { Knowledge donaing }\end{array}$ & + & 230 & Iran \\
\hline $\begin{array}{l}\text { Wijekoon, Ga- } \\
\text { lahtiyawe } 2016\end{array}$ & $\begin{array}{l}\text { Dynamic innovation } \\
\text { capability }\end{array}$ & $\begin{array}{l}\text { Knowledge exploration } \\
\text { and exploitation }\end{array}$ & + & 197 & $\begin{array}{l}\text { Sri Lan- } \\
\text { ka }\end{array}$ \\
\hline Ullah et al. 2017 & $\begin{array}{l}\text { Firm innovation ca- } \\
\text { pability }\end{array}$ & Knowledge sharing & + & 254 & Pakistan \\
\hline
\end{tabular}




\begin{tabular}{|c|c|c|c|c|c|}
\hline $\begin{array}{l}\text { Ullah et al. 2017, } \\
\text { 2017a }\end{array}$ & $\begin{array}{l}\text { Firm innovation ca- } \\
\text { pability }\end{array}$ & Knowledge sharing & + & 254 & Pakistan \\
\hline $\begin{array}{l}\text { Chang et al. } \\
2017\end{array}$ & $\begin{array}{l}\text { Firm innovation ca- } \\
\text { pability }\end{array}$ & Knowledge sharing & + & 1200 & Taiwan \\
\hline $\begin{array}{l}\text { De Vascoucelos, } \\
\text { De Oliveira } 2018\end{array}$ & $\begin{array}{l}\text { Firm innovation ca- } \\
\text { pability }\end{array}$ & $\begin{array}{l}\text { Information and know- } \\
\text { ledge obtained }\end{array}$ & + & 315 & Brazil \\
\hline $\begin{array}{l}\text { Sheng, Hart- } \\
\text { mann } 2019\end{array}$ & $\begin{array}{l}\text { Eksploracyjne i eks- } \\
\text { ploatacyjne zdolno- } \\
\text { ści innowacyjne }\end{array}$ & $\begin{array}{l}\text { Cross-border knowledge } \\
\text { tacitness sharing }\end{array}$ & - & 1000 & Taiwan \\
\hline $\begin{array}{l}\text { Tekin, Akyol } \\
2019\end{array}$ & $\begin{array}{l}\text { Firm innovation ca- } \\
\text { pability }\end{array}$ & Creating knowledge & + & 600 & Turky \\
\hline Migdali 2019 & $\begin{array}{l}\text { Firm innovation ca- } \\
\text { pability }\end{array}$ & $\begin{array}{l}\text { Knowledge management } \\
\text { (with all processes) }\end{array}$ & + & 273 & Jordan \\
\hline $\begin{array}{l}\text { Mazzucchelli et } \\
\text { al. in press }\end{array}$ & $\begin{array}{l}\text { Team innovation ca- } \\
\text { pability }\end{array}$ & Knowledge sharing & + & 265 & Italy \\
\hline $\begin{array}{l}\text { Zheng,Merchant } \\
\text { in press }\end{array}$ & $\begin{array}{l}\text { Firm innovation ca- } \\
\text { pability }\end{array}$ & Learning capability & + & 210 & China \\
\hline
\end{tabular}

While analyzing the data contained in table 1 , it can be seen that the results of research conducted by various scientists around the world confirm the view prevailing in the literature that this knowledge sharing mainly contributes to building innovation capability of organizations, however, other voices are also beginning to appear indicating, for instance the ability of organizational learning and focus on learning in the organization as an important source of its innovation capacity (e.g. Huang 2011, Zheng and Merchant, in press). What's more, while researchers agree on the fact that the process of knowledge sharing is important for building innovation capability of organizations, they do not agree on which elements of this process have a significant impact on shaping the discussed ability, e.g. research conducted by Yesil and colleagues (2013) showed that as part of the process of sharing knowledge, only the transfer of knowledge within an organization has a positive effect on its innovation capability, while the accumulation of knowledge does not significantly affect that capability.

It is worth adding that Faroukh and Sohal (2015) came to the opposite conclusions in their research, as a result, they stated that only the behaviour of employees employed in the field of knowledge collecting in the process of 
knowledge sharing has a significant impact on innovation capability. The researchers noted that it is necessary to emphasize the importance of knowledge sharing by the company's management and building an individual culture of knowledge sharing among employees.

In turn, Hussein et al. (2016) in their study showed that the readiness of members of the organization to collect, as well as donate knowledge, can affect the innovation capacity of teams.

Ullah et al. (2017; 2017a) showed that the process of knowledge sharing in general has a great impact on innovation capability, what is more, according to the mentioned researchers, knowledge sharing is the basic activity that an employee can undertake to increase the innovation capacity of an organization and enable it to achieve success. Employees who feel motivated, additionally undergo appropriate training are delighted with activities that are aimed at increasing the innovation capability of the organization.

Tekin and Akyol (2019) came to an interesting conclusion in their study, and stated that sharing knowledge within the organization and implementing knowledge management has no impact on the innovation capability of an organization. It turned out that sharing knowledge is insufficient to build innovation capacity when employees are not completely convinced that the management have provided them with full information, or when information has not been provided in a timely manner.

This conclusion is interesting because it is in opposition to the dominant view in literature.

It is also worth adding that researchers also point to other sources of the organization's innovation capability.

Liao et al. (2015) in their research showed that not only the knowledge sharing process but also knowledge transfer is of great importance for building corporate innovation capability. Mazzucchelli et al. (in press), in turn, pointed out that understanding how research and development units scattered around the world share knowledge with each other will allow for a better comprehension of the development process of innovation capabilities, in this respect, this study confirmed the centrality of social capital, at the same time emphasizing the role of its three dimensions in enabling the exchange of knowledge and improving the team's innovation capability in the context of distributed R\&D teams. According to the results of research, structural social capital, by enabling members of dispersed teams to build personal relationships and creating network ties, allows employees to create, share and discuss new ideas that are useful for improving and developing innovation capability (p. 7). 
Urgal and colleagues (2013) emphasized the importance of interacting with external sources of knowledge in their study, Sheng and Hartmann (2019) in their research highlighted the importance of tacit knowledge in multinational corporations for building innovation capability, while Migdali (2020) emphasized the importance of appropriate knowledge management in the organization in terms of innovation capability and innovative results.

\section{Conclusion}

As the author mentioned earlier, the notion of innovation capability is a complex, multifactorial and multifaceted concept that is closely related to the dynamism of the environment in which the organization operates. The concept of innovation capability emphasizes primarily the ability to reconfigure the resources held by the organization in the field of innovation, which is a response to changes taking place in the environment of the organization. It is also worth emphasizing that in an era where organizations must operate in a turbulent environment, the development of innovation capability becomes one of the conditions for conducting innovative activities effectively. Therefore, shaping innovation capability should be taken seriously by every enterprise.

The literature review carried out by the author shows that an important aspect in the process of building and developing organizational innovation capability is the knowledge sharing process, which confirms the view prevailing in literature, however, it turns out that researchers do not agree on which element of this process is more important for building and developing of such capability. Also noteworthy is the fact that there is not an unanimous view among researchers that it is knowledge sharing that is the most important factor for shaping and developing innovation capability, and therefore, the question of whether innovation capacity can be treated as a result of management processes or knowledge sharing cannot be clearly answered. Thus, in the future it would be worth conducting a study to determine the proportion of the impact of individual elements of both the knowledge management process and the knowledge sharing process on innovation capacity. Moreover, qualitative research aimed at identifying factors other than knowledge management that affect innovation capability could be beneficial as well. 


\section{Summary}

Organizational innovation capability as a result of knowledge management processes - a literature review

Nowadays, innovation and innovativeness have become a key conditioning factor in the survival of an organization. The organizations should have a sufficiently high level of innovation capability to be able to effectively develop and implement new solutions. Currently, researchers are increasingly talking about knowledge management processes in the context of creating and developing innovation capability of an organization (e.g. Hussein et al. 2016; Wijekoon and Galahitiyawe 2016). As noted by Hussein et al. (2016), sharing knowledge in a dynamically changing business environment is gaining key importance for the success of an organization. Knowledge itself, on the other hand, is indicated as a key source of innovation in the literature on knowledge management (Wijekoon and Galahitiyawe 2016; Monferrer et al. 2014; Nonaka et al. 2000; Yesil et al. 2013).

The purpose of this study is to show what kind of research problems / which research problems related to knowledge management in the context of creating and developing innovative capability are most often raised by representatives of science in the world and the second objective is an attempt to answer the question whether innovation capacity can be treated as a result of knowledge management processes.

Keywords: innovation capability, knowledge, knowledge sharing.

\section{Streszczenie}

Zdolność innowacyjna organizacji jako wynik procesów zarządzania wiedzą -przegląd literatury.

W dzisiejszych czasach innowacje i innowacyjność stały się kluczowym czynnikiem warunkującym przetrwanie organizacji. Aby organizacje mogły w sposób skuteczny opracowywać i wdrażać nowe rozwiązania powinny posiadać odpowiednio wysoką zdolność do innowacji. Obecnie w kontekście tworzenia i rozwijania zdolności innowacyjnych przez organizację badacze coraz częściej zaczynają mówić o procesach związanych z zarządzaniem wiedzą (np. Hussein et al. 2016; Wijekoon and 
Galahitiyawe 2016). Jak zauważają Hussein et al. (2016) dzielenie się wiedzą $\mathrm{W}$ dynamicznie zmieniającym się środowisku biznesowym zyskuje kluczowe znaczenie dla sukcesu organizacji. Zaś sama widza w literaturze zajmującej się zarządzaniem wiedzą wskazywana jest jako kluczowe źródło innowacji (Wijekoon and Galahitiyawe 2016; Yesil et al. 2013).

Celem niniejszego artykułu jest przedstawienie, jakie problemy badawcze związane z zarządzaniem wiedzą w kontekście tworzenia i rozwijania zdolności innowacyjnych są najczęściej poruszane przez przedstawicieli nauki na świecie i próba odpowiedzi na pytanie, czy można traktować zdolność innowacyjną jako wynik procesów zarządzania wiedzą.

\section{Słowa}

kluczowe: $\quad z$ dolność innowacyjna, wiedza, dzielenie się wiedzą.

JEL

Classification: O30, D83

\section{References}

1. Akhavan, P., Hosseini S.M., (2016). Social capital, knowledge sharing, and innovation capability:an empirical study of R\&D teams in Iran. Technology Analysis \& Strategic Management, No. 1, pp. 96-113. DOI: http:// dx.doi.org /10.1080/09537325.2015.1072622

2. Andreva, T., and A. Kianto. (2011). Knowledge processes, knowledge -intensity and innovation: Amoderated mediation analysis. Journal of Knowledge Management No. 15 (6), pp.1016-1034.

3. Calantone, R. J., S. T. Cavusgil, and Y. Zhao, (2002), Learning Orientation, Firm Innovation Capability, and Firm Performance. Industrial Marketing Management No. 31 (6), pp. 515-524. DOI: 10.1016/S0019- 8501(01)00203-6.

4. Chang, W.J., Liao, S.H., Wu, T.T., (2017). Relationships among organizational culture, knowledge sharing, and innovation capability: a case of the automobile industry in Taiwan. Knowledge Management Research and Practise, No. 15, pp. 471-490. DOI: 10.1057/s41275-016-0042-6

5. Chen L-J., Chen Ch-Ch., Lee W-R. (2008), Strategic Capabilities, Innovation Intensity, and Performance of Service Firms, Journal Services\&Management, no. 1, pp.111-122.

6. Darroch, J. (2005). Knowledge Management, Innovation and Firm Performance. Journal of Knowledge Management No. 9 (3), pp.101-115. DOI: 10.1108/13673270510602809. 
7. de Vasconcelos, R.B.B, de Oliveira, M. R.G., (2018). Determinants of innovation in micro and small enterprises: a management approach, RAERevista de Administração de Empresas. Journal of Business Management No. 58 (4), pp. 349-364, DOI: http:/ / dx.doi.org/10.1590/S0034-759020180402

8. Dimitrios, B., Ionnis, R., Efstathios, V., Christos, A., Dimitrios, T. and Labros, S. (2018). Successful and efficient knowledge management in the Greek hospitality industry: Change the perspective!, Academic Journal of Interdisciplinary Studies, No. 7(1), pp. 185-191.

9. Donate, M. J., \& Guadamillas, F. (2011). Organizational factors to support knowledge management and innovation. Journal of Knowledge Management, No.15(6), pp. 890-914.

10. Du Plessis, M. (2007). The Role of Knowledge Management in Innovation. Journal of Knowledge Management, No. 11 (4), pp. 1367-3270. DOI: $10.1108 / 13673270710762684$.

11. Hewitt-Dundas, N. (2006). Resource and Capability Constraints to Innovation in Small and Large Plants, Small Business Economics, No. 26, pp. 257-277. DOI: 10.1007/s11187-005-2140-3.

12. Huang, H. C. ( 2011). Technological innovation capability creation potential of open innovation: a cross-level analysis in the biotechnology industry, Technology Analysis \& Strategic Management Vol. 23, No. 1, pp., 49-63, DOI: 10.1080/09537325.2011.537105.

13. Hussein, A.T.T., Singh, S.K., Farouk, S., Sohal, A.S. (2016). Knowledge sharing enablers, processes and firm innovation capability. Journal of Workplace Learning, No. 8, pp. 484-495, DOI 10.1108/JWL-05-2016-0041.

14. Inkinen, H. T., Kianto, A., \& Vanhala, M. (2015). Knowledge management practices and innovation performance in Finland. Baltic Journal of Management, No. 10(4), pp. 432-455.

15. Lawson, B., \& Samon, D. (2001). Developing innovation capability in organisations: A dynamic capabilities approach. International Journal of Innovation Management, No. 5(3), pp. 377-400.

16. Liao, S.H., Hu, D.C., Chen, C.C., Lin, Y.L., (2015). Comparison of competing models and multi-group analysis of organizational culture, knowledge transfer, and innovation capability: an empirical study of the Taiwan semiconductor industry. Knowledge Management Research \& Practice, No.3., pp. 248-260. Doi:10.1057/kmrp.2013.46

17. López-Nicolás, C., and Meroño-Cerdán, A.L. (2011). Strategic knowledge management, innovation and performance. International Journal of Information Management 31: pp. 502-509. doi:10.1016/j. ijinfomgt.2011.02.003.

18. Martinez-Roman, J. A., Gamero, J., Tamayo, J. A. (2011). Analysis of innovation in SMEs using an innovative capability-based non-linear model: a study in the province of Seville (Spain), Technovation No. 31., pp. 459-475. DOI: 10.1016/j.technovation.2011.05.005. 
19. Mazzucchelli, A., Chierici, R., Tortora, D., Fontana, S., (in press). Innovation capability in geographically dispersed $R \& D$ teams: The role of social capital and IT support. Journal of Business Research, doi: https:/ / doi. org/10.1016/j.jbusres.2019.05.034.

20. Migdali, M.M. (2019). Knowledge Management Antecedents, Processes, Innovation Capability and Organizational Performance: An Empirical Investigation. Proceedings of the International Conference on Intellectual Capital, Knowledge Management \& Organizational Learning, pp.241-250, DOI: 10.34190/IKM.19.099.

21. Obłój, K. (2001). Tworzywo skutecznych strategii, PWE, Warszawa.

22. Patalas-Maliszewska, J., Kłos, S., (2013). Zdolność innowacyjna polskich małych i średnich przedsiębiorstw. E-mentor, No. 3(50). Retrieved from: http://www.e-mentor.edu.pl/artykul/index/numer/50/id/1027

23. Reid, F. (2003). Creating a Knowledge Sharing Culture among Diverse Business Units. Employment Relations Today, No. 30 (3), pp. 43-49. doi:10.1002/ert.10097.

24. Rifat, K., \& Fusun, B. (2010). The influence of knowledge sharing on innovation. European Business Review, No. 22(3), pp. 306-317.

25. Romijn, H., and Albaladejo, M. (2002). Determinants of innovation capability in small electronics and software firms in Southern England. Research Policy No. 31, pp. 1053-67. https://doi.org/10.1016/S0048$7333 \% 2801 \% 2900176-7$.

26. Saunila, M. (2014). Innovation capability for SME success: Perspectives of financial and operational performance. Journal of Advances in Management Research, No. 11(2), pp. 163-175.

27. Saunila, M. (2016). Performance measurement approach for innovation capability in SMEs. International Journal of Productivity and Performance Management, No. 65(2), pp. 162-176.

28. Sheng, M.L., Hartmann, N.N. (2019). Impact of subsidiaries' cross-border knowledge tacitness shared and social capital on MNCs' explorative and exploitative innovation capability. Journal of International Management No. 25, pp. 1-16. DOI: https://doi.org/10.1016/j.intman.2019.100705

29. Stawasz, E. (2014). Dynamiczna zdolność innowacyjna - wybrane zagadnienia. Acta Universitatis Lodziensis Folia Oeconomica, No. 4(305), pp. 97-105.

30. Subramaniam, M., and Youndt M.A. (2005). The influence of intellectual capital on the types of innovative capabilities. Academy of Management Journal 48: 450-63.

31. Teece, D.J. (2007). Explicating dynamic capabilities: the nature and microfoundations of (sustainable) enterprise performance. Strategic Management Journal, No. 28(13), 1319-1350. DOI: https:// doi.org/10.1002/ smj.640. 
32. Teece, D.J., Pisano, G. \& Shuen, A. (1997). Dynamic capabilities and strategic management. Strategic Management Journal, No. 18(7), 509-533. DOI:https:// doi.org/10.1002/(SICI)1097- ～0266(199708)18:7<509::AIDSMJ882>3.0.CO;2-Z.

33. Tekin, Z., Akyol, A. (2019). The effects of knowledge and innovation management processes on innovation capability and new product development success. BMIJ No. 7(1), pp. 1-23. DOI: http://dx.doi. org/10.15295/bmij.v7i1.1024.

34. Ullah, M.I., Ab Hamid, K.B., Shahzad, A. (2017a). Impact of Motivation and Supervisory Support to Enhancing the Innovation Capability of Dairy Farms in Pakistan, Pakistan Journal of Life and Social Sciences, No. 1, pp.11-17.

35. Ullah, M.I., Ab Hamid, K.B., Shahzad, A., Mahmood, Z. (2017). Enhancing the Innovation Capability in Dairy Farms through Knowledge Sharing, Pakistan Journal of Commerce and Social Sciences, No. 1, pp. 89-104.

36. Urgal, B., Quintás, M.A., Arévalo-Tomé, R. (2013). Knowledge resources and innovation performance: the mediation of innovation capability moderated by management commitment. Technology Analysis \& Strategic Management, No. 5, pp. 543-565. http://dx.doi.org/10.1080/09537325.2013. 785514.

37. Wang, C. L., Ahmed, P. K. (2007). Dynamic capabilities: a review and research agenda, International Journal of Management Reviews, vol. 9, no. 1, pp. 31-51. DOI: https://doi.org/10.1111/j.1468-2370.2007.00201.x.

38. Wijekoon, A., Galahitiyawe, N.W.K. (2016). Innovativeness of IT Entrepreneurial Firms: The Roles of Knowledge Management and Dynamic Innovation Capabilities. Sri Lankan Journal of Management, No. 2., pp. 37-62.

39. Yaghoub, M., Teymourzadeh, E., Bahadori, M., Ghardashi, F. (2017), Conceptual Model of Innovation Capability in Industrial and Academic Research Centers: A Systematic Review. Iranian Journal of Management Studies, No. 3, pp. 609-640. DOI: 10.22059/ijms.2017.238379.672756.

40. Yaghoubi, M., Javadi, M. \& Agha Rahimi, Z. (2011). The relationship between knowledge management and demographic features of students in Isfahan University of medical sciences. Iranian Journal of Medical Education, No. 10(5), pp. 831-838.

41. Yesil, S., Koska, A., Buyukbese, T. (2013). Knowledge Sharing Process, Innovation Capability and Innovation Performance: An Empirical Study. Procedia - Social and Behavioral Sciences No. 75, pp. 217 - 225.

42. Zafarian, R., Mohammady Elyasi, Q., Farokh Manesh, T. \& Movahedy Pur, N. (2012). The role of the network capital on the ability of innovation organization (Case study: Advanced manufacturing companies). Entrepreneurship Development, No. 5(3), pp. 7-26.

MONIKA INKÓW 
43. Zhang, M., Merchant H. (in press), A causal analysis of the role of institutions and organizational proficiencies on the innovation capability of Chinese SMEs, International Business Review, https:/ / doi.org/10.1016/j. ibusrev.2019.101638.

44. Zheng, S., Zhang, W., Wu, X., \& Du, J. (2011). Knowledge-based dynamic capabilities and innovation in networked environments. Journal of Knowledge Management, No. 15(6), pp. 1035-1051. DOI: 10.1108/13673271111179352.

45. Zurina, A., Hazman, S. A. \& Jasmine, A. (2011). Direct influence of human resource management practices on financial performance in Malaysian R\&D companies. World Review of Business Research, No.1(3), pp. 61-77. 